University of Nebraska - Lincoln

DigitalCommons@University of Nebraska - Lincoln

Faculty Publications, Department of History

History, Department of

2012

\title{
Territorial Bonds: Indenture and Affection in Intercultural Arizona, 1864-1894
}

Katrina Jagodinsky

University of Nebraska-Lincoln, kjagodinsky@unl.edu

Follow this and additional works at: https://digitalcommons.unl.edu/historyfacpub

Jagodinsky, Katrina, "Territorial Bonds: Indenture and Affection in Intercultural Arizona, 1864-1894" (2012). Faculty Publications, Department of History. 143.

https://digitalcommons.unl.edu/historyfacpub/143

This Article is brought to you for free and open access by the History, Department of at DigitalCommons@University of Nebraska - Lincoln. It has been accepted for inclusion in Faculty Publications, Department of History by an authorized administrator of DigitalCommons@University of Nebraska - Lincoln. 


\title{
Territorial Bonds
}

\author{
Indenture and Affection in Intercultural \\ Arizona, 1864-1894
}

Katrina Jagodinsky

\begin{abstract}
Borderlands families have never had it easy, and the second half of the nineteenth century was no exception. In an act of love and power, American and Hispano families reached out to Indian women and children to ease their borderlands burdens. Lieutenant Colonel King S. Woolsey left his central Arizona ranch in 1864 to kill Apaches and claim land; he returned from his campaign with a ten-year-old Yaqui girl as his personal consort. Lucía Martínez bore the Colonel's children and harassment until his death in 1879. The territorial patriarch left his illegitimate children no inheritance, but he had indentured them, ironically making them eligible for $\$ 1,000$ from his estate. Woolsey's compatriot Jack Swilling had brandished a gun to uphold slavery, claim Western lands, and make "good Indians," but when his Mexican, American, and O'odham friends staged the Camp Grant Massacre in the spring of 1871, he stayed home with his Mexican wife, four American children, and four Apache wards. Swilling indentured one of these Indian minors, but he most likely did so to protect him from his neighbors' anti-Apache sentiments. Josefína and Miguel Gonzales Roca indentured three-year-old Teutílla in 1869. Of elite families in Mexico and Chile, the Rocas had been nursed and cared for by criadas - mestizo servants-and they wanted the same for their children. When they indentured the Apache toddler, they both continued a longtime Hispanic tradition of dependence upon racially inferior domestics and secured a future of white privilege for their new family.

This chapter focuses on intercultural households to examine linkages between bonds of indenture and ties of affection, between exploitative labor and love, and between questionable paternity and patronage. Though Woolsey, Swilling, and Roca have been chronicled as Arizona's territorial fathers, the profiles
\end{abstract}


offered here emphasize their participation in the indenture system and their roles as heads of hierarchical households. By constructing histories from the evidence that others have ignored or obscured, this chapter addresses not only territorial Arizonans' intimate dependence on racial others but also the legacies of those intimacies in the state's historiography.

Between 1864, when Arizonans held their first legislative session, and 1894, when Phoenix Indian School administrators initiated a southwestern model of the "outing system," citizens used the indenture of American Indian children to strengthen their tenuous claims to the contested borderland territory. Legislators regulated domestic sites through the Howell Code, the body of law passed in 1864 that governed intercultural households. The Howell Code privileged white patriarchs, though not all Arizona heads of household claimed their racial and sexual privileges equally. Home to Mexicans, Europeans, Americans, Confederates, free blacks, Chinese, and Indians, the territory fostered racial ambiguities that senators sought to clarify in the Howell Code. ${ }^{1}$ Citizens' dependence on nonwhite labor complicated official efforts to discourage intercultural intimacies. Working together often meant living together, which usually led people to share stories and secrets, germs and jokes. The three households analyzed here demonstrate that where there was exploitation, there was also affection-sometimes mutual, sometimes not-and that the indenture of minor Indians was merely one phase in a long history of labor and intimacy in the Southwest. ${ }^{2}$

Arizona's territorial senators did not create a coercive Indian labor market; rather, they formalized what had been an extralegal trade that featured interracial intimacies. The southwestern slave market connected Comanches and Seris, Utes and Pueblos, Mormons and Catholics; it predated the Arizona legislature and continued nearly into the twentieth century. Americans, Indians, and Mexicans who participated in this market targeted women and children for their reproductive and acculturative capacities, even as they murdered captives' male relatives in the struggle for frontier dominance. Slavers took advantage of racial ambiguity and sold Mexicans as Indians, redeemed Indians as white Mexicans, and tattooed Indianness onto white slaves. Though tribes often enslaved enemy tribal members, they sometimes incorporated them into their own families, linking exploitative labor and fictive kinship, as shown in Joaquín Rivaya-Martínez's study of Comanche enslavement in this volume. Hispanos did the same, drawing indigenous slaves into a complex caste system where they intermarried with free laborers and served elites as criados. As long as this system remained extralegal, American officials struggled to deter intercultural bonds that often formed as a result of the slave trade. Such widespread mestizaje made it difficult to distinguish citizen from subject, patriarch from peon, respectable from rogue. In an unregulated market, territorial Arizonans bought laborers for companionship as well as for apprenticeship; they bought children to replace those who had died; 
they bought their way into an intercultural network that blurred the bonds of affection and indenture. ${ }^{3}$

In July of 1864 , Lucía Martínez escaped Apache slavers. Just ten years old, the Yaqui girl outwitted her captors and began the more than two-hundred-mile trek from the central Arizona highlands to her southern Sonora home. Only a few miles into her escape, however, Lucía encountered Alabama-native Lieutenant Colonel King Woolsey leading an anti-Apache expedition along the Black River. The Colonel claimed the child for himself and took her back to his ranch, Agua Fria, near the territorial capital of Prescott. When he returned from his violent campaign, Woolsey's neighbors elected him to serve in the territory's first legislative session. ${ }^{4}$

On November 10, 1864, King Woolsey and his fellow senators approved a nearly five-hundred-page legal code addressing the civil and criminal conduct of all men and women, minors and adults, citizens and subjects. Known as the Howell Code, it defined deviant and acceptable behaviors and put into place the rules that made public the private details of territorial Arizonans' lives. The federal government had withheld citizenship status from Native peoples, but Woolsey and his peers constructed a broad range of laws to circumscribe the daily interactions between indigenous and newcomer westerners. The Howell Code codified racial and gender hierarchies that were widely contested throughout the ethnically diverse and demographically imbalanced territory, so that Arizona might become recognizable as a modern state ruled by respectable white men. When Woolsey signed the Howell Code, he affirmed his claims to young Lucía Martínez's body and labor. ${ }^{5}$

William T. Howell, appointed territorial Arizona justice, drafted a set of laws in anticipation of the 1863 Organic Act making the region a United States territory. Howell found the laws of California suitable to the social customs and racial hierarchies endorsed by Arizona's Anglo elites, so he adopted most of the neighboring state's legal code. Its peonage and indenture laws offered little protection to nonAnglos, but California law favored white women's property and marital rights. Howell continued the trend away from coverture but offered women few political rights, and overall the code upheld white male supremacy in the application of criminal and civil law, particularly where women's bodies were concerned. ${ }^{6}$

Arizona legislators, like many of their western and southern counterparts, fixed the age of sexual consent for all females at ten years, defining girls as potentially sexually active prior to menarche, but they set girls' marriageable age at sixteen. Females over ten years old who withheld consent had to prove sexual assault through evidence of physical injury, could not deny their husbands sexual access, and faced a prison term of at least five years if they terminated a pregnancy. ${ }^{7}$ Between 1864 and 1871, the span of years Lucía spent under Woolsey's custody, nonwhite Arizonans could not testify in criminal cases against white 
men, rendering nonwhite sexual assault victims silent if their attackers were white. After 1871, legislators granted all residents the right to testify in criminal trials, though no indigenous woman testified against a white defendant until 1913 and nonwhites remained barred from testimony in civil trials until 1912. ${ }^{8}$

Arizona's pioneer fathers continued to have sex on their mind when they passed a provision banning mixed-race marriages. ${ }^{9}$ Though Indians, Mexicans, and Anglos lived in close proximity, legislators ensured that sexual relations among these groups would remain illicit. Indigenous women could not use the courts to uphold the spousal rights that American women enjoyed, and Mexican women depended upon judges' discretion to enjoy white marital privileges since they might easily be seen as Indian. ${ }^{10}$ Importantly, the miscegenation law did not make interracial intercourse criminal: the code simply put the burden of illegitimate progeny on the mother, deviating from the common-law presumption of patrilineality. This seemingly race-neutral move, very familiar to legislators from slaveholding families, kept property in the hands of white fathers who practiced procreative sex with racially ambiguous and socially vulnerable women. ${ }^{11}$

Legislators' concerns regarding miscegenation in the territory stemmed from their exposure to mestizaje under the intertribal slave trade in the southwestern borderlands. ${ }^{12}$ The first territorial governor recognized that citizens' dependence upon Indian labor could foster interracial promiscuity. In his 1864 address to the legislature, Governor John Noble Goodwin advised Woolsey and other politicians to regulate such relations as he simultaneously linked Indian servitude to the ongoing Apache wars. "In the fierce conflicts for life waged ... with the... Apaches, some young persons have been captured, and ... placed in families as servants... I can suggest no better enactment ... than a system of apprenticeship similar to that existing in most of the states." ${ }^{13}$ The territorial indenture system, then, constituted a pivotal shift between an extralegal slave trade and institutionalized unfree labor while also serving to discourage interracial bonds of affection. As the Woolsey, Swilling, and Roca households illustrate, however, not all Arizonans used indenture to distance themselves from minor Indians or to discontinue pre-American labor systems. ${ }^{14}$

Elected officials wrote a provision entitled "Of the Support of Minor Indians" in response to Governor Goodwin's concern for young Apaches. The law declared that "any person into whose care or custody shall come any captive Indian child of a hostile tribe, or any minor Indian child of other than hostile tribes, shall, within twenty days thereafter, produce such child before the judge of probate or a justice of the peace ... and may apply to ... have such Indian child bound to him until he shall arrive at the age of twenty-one years; and if a female, at the age of eighteen years." ${ }^{\text {i5 }}$ The "Minor Indian" law did little to protect the welfare of indigent children, as did other western laws regulating minors, indenture, and guardianship. Just a year after the Emancipation Proclamation had freed black slaves and the California 
legislature had dismantled its own Native indenture system, Arizona lawmakers institutionalized the region's tribal slave trade by legalizing the abduction and forced labor of minor Native Americans. Between 1864 and 1873, legislators barred citizens from adopting Indian children and required that heads of households with Indian minors in their custody apply for a bond of indenture within twenty days of taking custody. When they wrote an adoption law in 1873 , the legislature failed to mention indigenous children at all and upheld the "Minor Indian" law for fourteen more years, suggesting that they believed white minors should be adopted while Native wards should be indentured. The law granted local justices of the peace the authority to place Indian children in non-Indian households until the age of majority (eighteen for females and twenty-one for males) in exchange for good treatment, food, and clothing. Despite the governor's suggestion to borrow apprenticeship models from other states, the code did not make basic education or occupational training a component of indenture, leaving it to household heads to determine the most suitable work for young Native Americans. ${ }^{16}$

That Arizona citizens were at war with the indigenous population during the indenture period of 1864 to 1887 explains why Indian children were so widely available to settler-colonists and indicates that the statute regarding minor Indians was part of an extermination campaign waged against Native families. Woolsey captured Lucía while hunting Native Americans, Swilling described his orphans as children of "a tribe hostile to the Territory," and the Rocas called Teutílla a "captive Apache," making the children suitable subjects for servitude and linking indenture to anti-Indian sentiments. Geronimo's 1886 surrender marked an official end to the Indian wars in the territory, and when the $1887 \mathrm{Al}$ lotment Act held out the promise of citizenship to Native people, the territorial legislature repealed the indenture clause. Victoria Smith's study shows, however, that citizen families continued to capture indigenous children after 1887 without formally adopting them, indicating a continued interest in nonwhite child labor after the legislative assembly proscribed the practice. ${ }^{17}$

Arizonans could also use the Howell Code's statute on minor Indians to exploit Native women's reproductive and productive labor and continue an antebellum legacy of white men's sexual access to laboring women. ${ }^{18}$ Reproductive labor included domestic management of the household: food preparation, child care, material maintenance, and emotional support. ${ }^{19}$ Some masters also demanded sexual services. Having silenced indigenous voices through the witness exclusion provision and having legally defined Indian girls over ten as sexually available, the Colonel and his colleagues ensured that household heads enjoyed relatively free access to their servants' bodies with no concern for the support of illegitimate and mixed-race descendants. ${ }^{20}$ The law upheld white men's demands on subordinates' bodies and then required women to bear children that would likely become servants rather than heirs. 
Perhaps because he had a hand in drafting the Howell Code, King S. Woolsey applied most exactingly the aspects of the law that allowed him to exploit Lucía Martínez and their daughters' labors. The westering man made his wealth farming on Akimel O'odham lands, convinced his neighbors of his Union loyalties by supplying the U.S. military with foodstuffs during the Civil War, and earned his rank of lieutenant colonel by murdering Native Americans. He served as senator on and off between 1864 and 1877 before losing an 1878 bid to become a territorial delegate to Congress. Known to his servants as "Mr. King" and to his admirers as "the Colonel" or "the Honorable Mr. Woolsey," the southern frontiersman remains fondly remembered among Arizona history enthusiasts. ${ }^{21}$

From the age of ten to eighteen, Lucía Martínez served her master and his guests, who described Woolsey's ranch, Agua Fria, as a "little frontier establishment" that was organized according to the plantation model that Woolsey imported from the South. Woolsey's staff cook described the racialized table he and Lucía prepared each day: "First, there's the black men, i.e., Mexicans, the herders; then there's the white men, i.e. the carpenters, masons, etc.; then there's Mr. King, i.e. Woolsey and his friends; and last, I and ... the Indian girl, an Apache captive ..., and the dogs." 22

Bound to serve the needs of male and female guests legally and socially designated as her racial superiors, Lucía Martínez found herself in the midst of the southwestern peonage market despite her escape from the Apaches. The Colonel's household bore strong resemblance to a southern plantation in a borderlands context, and he might have had no qualms about enjoying both the sexual and servile labors he expected of his Yaqui servant if he had grown up among men who fathered slaves. ${ }^{23}$ Indeed, the laws he signed into place defined Lucía as sexually available and silenced her resistance to sexual advances. She gave birth to her first daughter at age twelve or thirteen, her second at fifteen, and she bore a son at seventeen. The Maricopa, Mexican, and O'odham men working for the Colonel may have recognized Lucía's subordinate and sexually vulnerable status as a component of the peonage and slave market, which relied heavily on women's reproductivity to forcibly cement kinship alliances. As Joaquín RivayaMartínez and Victoria Smith have found, female slaves who became mothers rarely escaped. ${ }^{24}$ The full range of the Yaqui girl's experience may be difficult for historians to ascertain, but certainly the men she lived with made significant claims on her productive and reproductive labor.

By the summer of 1871 Lucía could bear no more. She had just given birth to a lame son when the Colonel married Mary H. Taylor of Georgia, thus ensuring his access to yet another woman's domestic and bodily services. Martínez fled the ranch for Yuma a month after Woolsey and Taylor's wedding. The founding father detained their three- and five-year-old daughters but allowed her to take their infant son, Robert. The girls' mother fought for her children, filing a suit of 
habeas corpus for their custody through a Yuma proxy. Probate Justice John T. Alsop agreed that Clara and Johanna were too young to leave their mother, but he approved the Colonel's application for indenture and guaranteed the girls would serve their father once they reached a "suitable age." 25

In January 1879, when Johanna was thirteen and Clara ten, Woolsey visited Yuma and put his daughters-but not his son-into the orphanage at St. Joseph's Church. The Colonel had recently lost his campaign for territorial delegate and was now preparing to plant two thousand acres of wheat. Such a venture required that Woolsey increase his labor crew and domestic staff at his new Agua Caliente ranch southwest of modern-day Phoenix. Rather than putting his indentured daughters to valuable reproductive labor, as he had Lucía, the patriarch took the girls away from their Yaqui mother and put them under the care of the Catholic Church, using indenture as a way to sever the bond of affection between mother and children. He would not bring them into the home he shared with his wife, but neither would he allow his illegitimate family to remain together in Yuma. Almost fifteen years after he had abducted Lucía and just six months after he had taken her daughters from her, the Colonel suddenly died of apparent heart trouble. Soon the women he had mastered would face each other in probate court. ${ }^{26}$

The girls remained at St. Joseph's Catholic Church near Yuma, but Lucía once again fought for her daughters' few rights under the Howell Code. Woolsey's death constituted a forfeit of the $\$ 1,000$ indenture bond he had signed in 1871 that required him to provide for the girls' sustenance while they were under his custody. Though the senator had not taken direct custody of his daughters, he had assumed responsibility for them once he put them in St. Joseph's, and he remained financially accountable for their care up to $\$ 1,000$. The promise of payment on the bond, of course, helped Lucía find lawyers willing to assist her. The former legislator's widow challenged her husband's illegitimate family but lost because they made no inheritance claims. The nuns who cared for Clara and Johanna also sued Woolsey's estate for expenses incurred on his daughters' behalf, and the rancher's widow paid them what was owed "with the proviso that no acknowledgment of the legitimacy or adoption of any children [was] intended" by her payment. ${ }^{27}$

As she finessed Arizona's legal system to serve her daughters' interests, Lucía, now twenty-six, showed the same fortitude that she had displayed at ten years old, when she had escaped her Apache captors. Though the probate judge granted guardianship of Woolsey's daughters to the Sisters of St. Joseph's Church, Lucía managed to regain custody of them within a year. When the 1880 census agent came to her door in Yuma, the Yaqui woman claimed Mexican ethnicity for herself and her children, ensuring that none of them would be bound under the Howell Code statute on minor Indians again and that they would be listed as white on the census. She also claimed that she was a widow, and the Martínez family was again intact and looked remarkably ordinary on paper. ${ }^{28}$ 
Though Woolsey's biographers have romanticized or obscured his relationship to Lucía and his children, the Colonel's contemporaries criticized his treatment of them. When he ran for territorial delegate in 1878 , a scathing editorial published in Yuma's Arizona Sentinel denounced Woolsey for abandoning Lucía, Clara, Johanna, and Robert to the "charity of strangers" while he amassed his own fortune on the backs of others. ${ }^{29}$ When he died in 1879, the frontier hero's mourners acknowledged the surviving children but implied that they were the product of Woolsey's childless marriage to Mary Taylor-an implication that must have made her blood boil, since she had fought so hard to deny them in court. Such editorializing illustrates nineteenth-century Arizonans' ambivalence toward the exploitative nature of the Colonel's relationship to his children. He had clearly used indenture to keep minor Indians close to him rather than to deter interracial intimacy. When Clara died in 1947 , an obituary declared simply that she was born on "February 4, 1867, at the Woolsey ranch north of Prescott

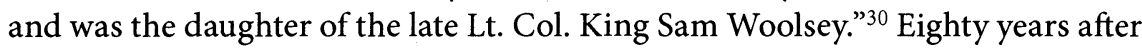
her birth, Clara Martínez had transformed from an Indian servant girl to a fondly remembered pioneer descendant.

The media's treatment of the senator and his children shows that many nineteenth-century Arizonans endorsed the racial and sexual hierarchies codified in the Howell Code but remembered ties of affection rather than bonds of indenture. Woolsey's reputation as a pioneer father was protected by twentiethcentury Arizonans who preferred to interpret the settlement collected by Clara and Johanna as an inheritance rather than a hard-fought indenture payment, and the laws that barred Woolsey's daughters from claiming an inheritance were easily forgotten by those who romanticized the bonds between Lucía and Woolsey as ties of love rather than power. These accounts suggest not only that the pioneer from Alabama wanted to marry Lucía and was tragically thwarted by the miscegenation law, but also that the courts upheld his daughters' claims to Woolsey's estate as heirs. Both interpretations fail to note that the territorial legislator voted in support of the miscegenation and indenture laws and that his children made claims against his estate based upon their indenture contract rather than upon his paternity. These biographers also disregard Lucia's remarkable use of the legal system to challenge the Indian killer's custody of his daughters, a bold move indicating that if there was any affection in their relationship, it was not shared. ${ }^{31}$

Jack Swilling's use of the Howell Code statute on minor Indians differed vastly from that of his neighbor, though he and Woolsey otherwise had much in common. Both men had left their southern families seeking military adventure in the West and had led anti-Apache expeditions in Arizona. These territorial fathers lived and worked closely among the Maricopas and O'odham in the Salt River Valley and, with the extensive aid of Mexican and Indian laborers, achieved their wealth through a variety of agricultural, mining, and commercial pursuits. 
Both frontiersmen served political office, though Swilling proved less able to maintain the genteel demeanor and polished reputation necessary to achieve political prominence among territorial elites. ${ }^{32}$

"Tragic Jack," as one of his biographers called him, settled in Arizona after his fellow Confederates were forced out of the region, and in 1864 he married Trinidad Escalante of Hermosillo, Sonora, shortly after they met in Tucson. Though the Treaty of Guadalupe Hidalgo had defined ethnic Mexicans as white citizens-just after they had defined themselves as mestizo during their War for Independencemaking this union legal under the Howell Code, Trinidad's views on her own racial status differed. "I don't claim to be white ... they don't call Mexicans white; I come from Sonora and they call me Mexican." ${ }^{33}$ Legally white but racially ambiguous, Trinidad Escalante bore five children to her husband during their fourteen-year marriage, and between 1864 and 1872 Jack Swilling brought at least four minor Indians into their home. Described as a home open to their Hispanic and indigenous laborers, the multiethnic Escalante-Swilling household represents a stark contrast to Woolsey's plantation model of the southwestern intercultural household. ${ }^{34}$

In the seven years that Lucía Martínez and her three children lived on Woolsey's rigidly ordered ranch, they and the other laborers never appeared in census records as members of his household. Guests described a full working ranch of Mexican and Anglo workers, a cook, and domestics, but Woolsey appeared in the 1864 special territorial census as a single farmer worth \$9,00o. Jack Swilling, on the other hand, listed his Mexican wife, American children, and Indian wards along with a myriad of laboring men as household members-a radical departure from other household heads who reported Indian minors as "servants" and "laborers." The only marks that distinguished Swilling's Apache wards from his American children in the 1870 census were the "W" and "I" entered in the enumerator's shaky hand. ${ }^{35}$

Trinidad and her husband reportedly hosted the first Catholic mass said in Phoenix and offered their home for use as the 1868 polling place for that settlement (Swilling was elected as justice of the peace in that election). Jack encouraged many to join his ditch-digging efforts and became known as the "father of Phoenix," even as some of his actions perturbed his Anglo neighbors. Learning of traditional O'odham irrigation methods, Woolsey's neighbor orchestrated a plan to irrigate the Salt River Valley and make the region more suitable for large-scale agriculture. His multilingual laborers called him Don Juan Capistrano for his reputation of dealing harshly with the culpable and gently with the vulnerable. ${ }^{36}$

An enigmatic man, Justice Swilling alternately upheld and broke down racialism in the Southwest: he served the Confederate Army but worked side by side with Pima laborers; he killed Apaches for the Arizona Volunteers yet refused to indenture the indigenous minors who lived with his own children; and he married a 
Mexican who denied her own whiteness. Unlike Woolsey's racially and sexually segregated ranch, the Swilling-Escalante settlement reflected the intimate and fluid nature of intercultural labor and kinship that must have characterized other southwestern households. Life might very well have been different for Lucía had Woolsey married a woman like Trinidad before he found the ten-yearold Yaqui girl in Arizona's highlands.

Jack Swilling's intercultural promiscuity did not serve him particularly well; perhaps he displayed too much love and not enough power. After irrigating Phoenix he lost control over the town site, and when his property ended up being four miles from the city center, he lost money. Despite his heroic contributions to Arizona's military and agricultural history, "Tragic Jack" suffered from an addiction to morphine and alcohol that stemmed from an 1854 head injury. His familiarity with racial inferiors combined with his intoxicated outbursts drove a friend to question the emotional man's suitability as a guardian of Indian children.

John Ammerman, whose marriage Jack had officiated just two years earlier, filed a habeas corpus petition against Swilling for Apache minors Guadalupa and Bonifácio Woolsey in July $\mathbf{1 8 7 1}$, just days after Lucía claimed her own children in the same courtroom. Perhaps Jack Swilling took the Apache Woolseys from his neighbor's ranch to ease Mrs. Woolsey's settlement into her new borderlands home. In any case, Ammerman's petition represented an appropriate course of action for citizens concerned about Native American minors in white households who had not been reported within twenty days of being taken into custody, as required under the Howell Code statue on minor Indians. Ammerman dropped the petition when Jack filed an indenture for another Apache minor, Guillermo (Gavilan) Swilling, a boy he favored enough to pass onto him his surname. In filing this legal claim to Guillermo's services, Jack effectively barred other neighbors and "friends" from interfering with his Native wards during the aftermath of the Camp Grant Massacre, during which American, Mexican, and O'odham men killed more than 140 Apaches camped along Aravaipa Creek. In the months that followed, Camp Grant survivors shared concerns that kidnapped Apache "boys will grow up slaves, and ... girls, as soon as they are large enough, will be diseased prostitutes to get money for whoever owns them." ${ }^{\text {37 }}$ Swilling's indenture of Gavilan may have been a protective gesture meant to shield his indigenous children from the anti-Apache sentiment growing among his neighbors. ${ }^{38}$

That Justice Swilling favored Guillermo was made most evident in a studio photograph taken of the boy and his patron around 1875 . The photo offers a range of interpretive possibilities. Viewed as a portrait of father and son, the image seems to highlight the tension between miscegenation laws and the persistence of interracial intimacies as the two stare into the camera with remarkably similar gazes. The veteran casually grips his weapon over his shoulder with the confidence of a father who had taught his adolescent son to shoot straight and true, 


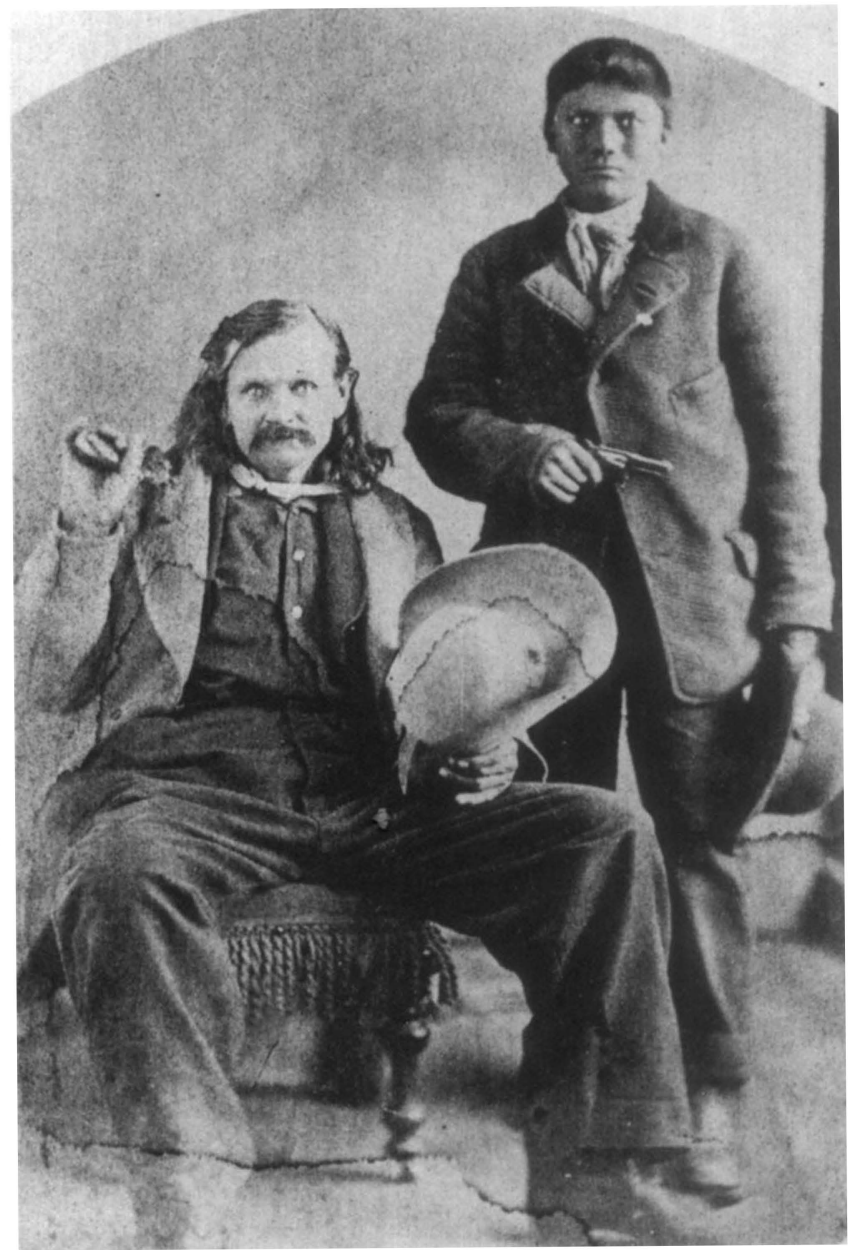

FIGURE 11.1. Jack Swilling with his Apache ward Guillermo Swilling, ca. 1875. Courtesy of Arizona State Library, Archives and Public Records, History and Archives Division, Phoenix, no. 98-003.

while his ward clutches his weapon with the timidity of a boy about to prove himself a man in one shot. Biographer Al Bates claims that Trinidad explained the photo as a family joke, meant to poke fun by overplaying Jack's desperado image and posing Guillermo as his fierce Indian bodyguard. Regardless of the justice's intent, the image clearly depicts the slippage between bonds of indenture and bonds of affection that the Howell Code aimed to discourage. Jack and Guillermo Swilling's bond is so readily apparent, in fact, that historians celebrating Arizona's 




FIGURE 11.2. Portrait of Jack Swilling with Guillermo Swilling removed, ca. 189o. Courtesy of Arizona State Library, Archives and Public Records, History and Archives Division, Phoenix, no. 98-002.

past as one in which Anglo "pioneers ... toiled and suffered gentling the Arizona Territory" (emphasis added) prefer a cropped version of the photograph that erased the Apache boy from this image (the only one of Jack Swilling) in order to remove evidence of extralegal intimacies and inside jokes that deflated territorial racialism. ${ }^{39}$

Though the tragic hero's excised portrait is widely circulated, and many tout him as the father of Phoenix, few historians have proven willing to address the 
intercultural complexities depicted in these photographs or the privileges of whiteness upheld in the Howell Code. In their biographies, Bates and Wilson recognize Guillermo's presence in Swilling's household, though neither acknowledges Bonifácio and Guadalupa Woolsey or Mariana, the three other Indian children who appeared in Swilling's census records. Bates claims that the Confederate indentured Guillermo because adoption was not allowed under the legal code until 1873, supporting the notion that Jack used indenture as a protective and paternalist measure. ${ }^{40}$

Swilling died in Yuma prison in 1878 , falsely charged with armed robbery. The circumstances of his arrest indicate that well-placed officials wanted the renegade tried regardless of his innocence. His tragic end was the result of flouting his fellow citizens' interest in white supremacy: he lived intimately with Apaches and Mexicans, used indigenous methods to irrigate metropolitan Phoenix, and poked fun at miscegenation and hysteria about hostile Indians. From his prison deathbed Swilling wrote an open letter to his fellow Arizonans. Appealing to the mercy of his peers, he wrote, "From the Governor down to the lowest Mexican in the land have I extended my hospitality, and oh, my God, how am I paid for it all. Thrown into prison ... [t] aken from my wife and little children who are left out in this cold world all alone. Is this my reward for the kindness I have done to my fellow men?"4l Swilling decried those who repaid him for his interethnic intimacies with false imprisonment. After his death, Trinidad struggled to care for her four American children, one of them born the year of Jack's death. The widow suffered financially and could barely support her own children, let alone her husband's Apache wards. She married German immigrant Henry Shumaker after 1887, but the Indian children raised in her Salt River Valley home disappeared after Jack's death, an ephemeral legacy of Arizona's intercultural past. ${ }^{42}$

Josefína and José Miguel Gonzales Roca's household in territorial Tucson offers yet another model of indenture within Arizona's intercultural families. Whereas Woolsey and Swilling were free to form multiethnic households because their whiteness was unquestionable, Roca used the racial and sexual hierarchies within his household to bolster his family's perceived whiteness in the presidio. Nicknamed "el Chileño orgulluso" for his nationalist pride, Roca was the son of a wealthy transnational merchant based in Concepción, Chile. After a French education and a brief but wild youth among well-connected schoolmates in Hermosillo, Roca married Josefína Mariana Haro y Samaniego, who was from an elite Sonoran military family. The couple suffered vandalism and lost $\$ 20,000$ of goods and property during the French intervention and moved to the United States in 1864, making their way to the American pueblo in $1867 .{ }^{43}$ When they arrived in Tucson, the Rocas anglicized their names to appear less Mexican and more white-though not necessarily American. José Miguel Gonzales y Roca became Miguel Gonzales Roca and Josefína Mariana Haro de Gonzales became Josefína Roca. ${ }^{44}$ 
The Rocas would have eight children, and Miguel bragged that each of them was born under a Chilean flag that he draped ceremoniously over his wife's birthing bed while she strained in the throes of labor. Though Josefína's children were born American citizens, her husband never relinquished his foreign citizenship. Tucson Hispanics enjoyed substantial political influence between 1869 and 1877 under territorial governor Anson P. K. Safford, and the Rocas managed to increase their family's status into the twentieth century, even if they are not now widely remembered as an important Hispanic family. The maintenance and display of a patriotic household staffed by racially inferior laborers, in addition to a significant name change, allowed the Rocas to cultivate their political and social influence in an increasingly Anglophile city. ${ }^{45}$

Roca's upper-class Latin American background instilled in him an interest in the preservation of whiteness and male dominance within multiethnic households that he shared with the senators who enacted the Howell Code. The Chilean caste system favored elites who enjoyed the services of racially other wet nurses, domestics, and field-workers. Unlike the slave labor systems familiar to Woolsey and Swilling, the South American model recognized (but did not always uphold) the legal rights of unfree laborers and did not criminalize manumission or mestizaje. Born seven years after the abolition of slavery in independent Chile, el Chileño orgulloso brought with him to Tucson a sense of his own white and patriarchal superiority that he shared with Anglo territorial elites, even if he also recognized his laborers' rights to fair-though not equal-treatment. ${ }^{46}$

In indenturing Teutílla in 1869, Roca both continued a Chilean tradition and demonstrated his conformity to Arizona's social institutions. Under the criada system of lifelong servitude, the lower caste remained subject to exploitation by elite whites, and a system of servant child distribution emerged in the newly independent and abolitionist Chile, where Roca was raised. In a society bounded by "relations of dependence," 47 wage-earning mothers often placed their children as domestics, or criados, in elite homes. A lifetime of servitude represented the best such mothers could provide for their children, and elite families took in minor servants to display their philanthropic patronage of lower castes. When the merchant indentured three-year-old Teutilla in 1869, the minor Apache joined three other female servants in the Roca household. ${ }^{48}$

The family successfully displayed both their wealth and whiteness through Teutílla's servitude. A destitute minor, three-year-old Teutílla likely had few options, and the merchant's family proved its wealth by promising to provide her fifteen years of food and clothing in exchange for her obedience and faithfulness. The indenture record described the economic contract between the merchant and the captive as a sentimental bond, suggesting that the indigenous girl would work in exchange for her master's "kindness." Such an arrangement likely appealed to the elite sensibilities of el Chileño orgulloso, and the bond allowed Roca 
to prove himself a charitable member of Tucson's white society. The Howell Code's statute on minor Indians required that probate judges inquire into the suitability of indenture petitioners. The Roca family may have sought this judicial stamp of respectability as a means to highlight their whiteness. The contract also allowed Josefína Roca to establish herself among the settlement's female elites as she signed the legal document alongside her husband, representing her vested interests in the domestic affairs governed by the Howell Code. In signing together, the Rocas agreed to uphold white supremacy by pledging to benefit from nonwhite labor, and they recognized the separate spheres of influence characteristic of Victorian gender roles: Josefína would manage the domestic laborers as Miguel exercised authority over the legal contracts that bound them. In conforming to intercultural household order within territorial Tucson, the mercantile family could afford to display their flamboyant Chilean national pride without risking their claims to wealth and whiteness. ${ }^{49}$

The Roca family's use of multiethnic laborers reflected their shifting needs for reproductive and productive labor between 1870 and 1880 . Renamed Tontíllar Roca, the girl worked under criada Juana Castillo's direction in 1869, while Castillo's seven-year-old son Prudencio probably aided eighteen-year-old criado Reyno Moreno. Tontíllar attended at least two births and watched over four children while she lived with the Rocas in the 1870s. Just a child herself, the Apache minor must have grown attached to the Roca women and children that she was contracted to care for. By 1880 , Josefína's daughters were old enough to help manage the family's domestic economy, and the servant staff had changed. Tontíllar had disappeared but had been replaced by a twenty-six-year-old Native American woman named Andrea, who likely devoted much of her attention to Josefína's three-year-old granddaughter. Four men joined Andrea: an Indian laborer her age, two white laborers, and a fourteen-year-old boy working in the store. Andrea and the other criados were all from Mexico. This creative mix of paid and unpaid, female and male, and domestic and commercial laborers further demonstrates a Hispano influence on indenture in the Roca's multiracial and multigenerational household. ${ }^{50}$

Racialized shifts in territorial politics required el Chileño to solicit white allies actively in order to ensure the continuation of his family's prominence in Tucson. Josefína hosted local lawyers, bankers, and publishers for lavish dinners during which she displayed her family's wealth through her servants' obedience and her daughters' propriety. While nonwhite criados waited on them, the Roca daughters flirted with their brothers' American friends visiting from preparatory school. By hosting dinner parties that featured nonwhite servants, the Rocas proved their ability to manage relations of dependence within their home and illustrated their willingness to participate in racial and sexual hierarchies outside their home during a crucial time in Arizona's Hispanic history. Each of these 
private events provided public evidence of the Rocas' conformity to American racialism, thus performing their whiteness within an increasingly segregated borderlands community. As Josefína and Miguel invited citizens to scrutinize their racially stratified household, they sealed their status on the upper rungs of the territory's racially stratified society.

The use of nonwhite labor within the Roca household proved the merchant's respectability and allowed him to escape the racial degradation that befell many Mexican families in turn-of-the-century Tucson. When Miguel died in 1886, his daughter Erminía married Ben Heney, who briefly served as mayor of Tucson in 1909. Heney's son Lautaro served as Tucson city councilman from 1933 to 1939, and in 1935 his granddaughter Frecia received a personal invitation to dine with President Franklin Roosevelt. Lautaro's son Paul actively served Arizona's Latino community during his impressive legal career. ${ }^{51}$

Sometime after his death, the merchant's family donated his flag stand to the Arizona Pioneers' Historical Society to honor the banner of Chileño paternity that the first generation of American Rocas had been born under. Whether archivists viewed the artifact as evidence of an Apache criada's care for a Mexican woman bearing American children to a Chilean father is difficult to say, but they likely saw its connection to both love and power. ${ }^{52}$ Considering the notoriety of Roca's children and grandchildren in comparison to the relative obscurity of Woolsey's and Swilling's children, surprisingly little has been written about Tucson's Chilean patriarch. Yndia Smalley Moore, Josefína and Miguel's granddaughter, served as director of the Arizona Pioneers' Historical Society from 1959 to 1964 but did not use the post to celebrate her Hispano past. Instead, she and her father, George Smalley, wrote a memoir that emphasized an Anglo family history. Yndia's cousin, Paul Roca, researched and wrote about Mexico's Jesuit past but saved his own genealogy for short letters that inadvertently found their way to the Arizona Historical Society. ${ }^{53}$ Family documents contain letters written by Miguel Roca in 1885 that seem to indicate he planned to kill himself, which might explain why his descendants-though proud to claim a pioneer past-chose not to emphasize him in their family histories. No one described Teutílla's care for the children or the family's reliance on nonwhite labor either, but having criadas they could ignore marked the Rocas as a white family of privilege.

Lucía, Clara, and Johanna Martínez, Guadalupa and Bonifácio Woolsey, Mariana, Guillermo Swilling, and Teutílla Roca were not the only Indian women and children drawn into the bonds of indenture and affection that characterized the intercultural labor market in territorial Arizona. The families claiming indigenous minors' labor under the Howell Code rarely acknowledged the contributions of these unfree members of their households. Colonel Woolsey, "Tragic Jack," and el Chileño felt no need to explain the presence of Native children in their homes, most likely because their contemporaries asked no questions. Louis 
John Frederick Jaeger, a prominent ferryman in Yuma, indentured a Native American girl named Mary at her mother's request around 1871 and drew no one's attention in doing so. In 1871, Carmena Campbell, a wealthy Arizona divorcee, indentured Indian girl Susan in Maricopa County. The same Maricopa County probate judge bound Indian boy Jim to Richard DeKuhn in $1873 .{ }^{54}$

Relationships between Native minors and their masters were sometimes exploitative and sometimes affectionate, but in any case they were usually overlooked. The reasons territorial Arizonans ignored Indian servants are difficult to determine, but the presence of these children in territorial Arizona is undeniable. Census records may show only a handful of indigenous wards serving Hispanic and Anglo households between 1860 and 1880, but men like Woolsey told half-truths to those collecting census information, and servants like Teutílla looked Mexican to enumerators. That Mariana and Gavilan are the only children featured in this chapter who actually appeared as "Indian" in census records proves the fallibility of census data in chronicling Native American labor in multiethnic households. In browsing census records between 1860 and 1880 , it becomes clear that enumerators and reporters creatively and inconsistently documented ethnic identities and household relations throughout the territory. Given such widespread misreporting, it is surprising that any evidence of minor Indian servitude exists at all. Such unreliable data makes it difficult to know how common the Woolsey, Swilling, and Roca families were, but their very insignificance to contemporaries and chroniclers indicates the normalcy of indigenous laborers.

The Howell Code's statute on minor Indians represents territorial Arizonans' management of the intertribal slave trade that indigenous and Hispanic actors once dominated. The institutionalization of white male privilege that justified nonwhite exploitation under the guise of a free labor system marked a significant step in state formation. Legislating citizen Arizonans' subordination of indigenous people defined as enemies of the state proved an effective method of controlling and consuming Native American resources, including Indian child labor. Additional provisions of the Howell Code ensured there would be few consequences for those who overstepped the intimate bounds of the law, and where interracial intimacies occurred, they could be defined as illicit and illegitimate.

Mixed-race and indigenous Arizonans lived and worked in close proximity to Americans throughout the territorial period, even as official policies sought to maximize the social and geographic distances between them. The boarding school system satisfied those who feared alcoholism and miscegenation as the byproducts of interracial intimacy, as well as others convinced that reservation seclusion fostered indolence and savagery. The Phoenix Indian School (PIS), established in 1891, provided a compromise between citizens' reliance on Indian women's and children's labors and legislators' discomfort with unregulated multiethnic households by putting Native children into institutions rather than families. 
Carlisle Indian School founder Richard Pratt proposed the outing system as a way to institutionalize familial relations and ease assimilation. Though he feared Westerners would abuse Native domestics, Pratt believed that putting Indian students into white households for short periods would enhance boarding schools' curricula. In 1894 the outing system - as it was applied in Arizona-put the regulation of citizen use of indigenous women and children's bodies under federal and philanthropic, rather than local and civil, jurisdiction. Although a continuation of the exploitation of Native American labor practiced under the indenture system, outing policies proposed strict segregation of minor Indian supervision by sex, thereby empowering matrons such as Trinidad Swilling and Josefína Roca while discouraging abusive patriarchs such as Woolsey. ${ }^{55}$

The outing system allowed PIS administrator Harwood Hall to bind minor Indians to the relations of dependence defined in the Howell Code without the risk of affectionate bonds being formed through indenture and guardianship arrangements. Brief exposure to domestic, agricultural, or industrial labor would train PIS students to serve their white superiors, while the interventions of field matrons and school supervisors would train citizen Arizonans to distance themselves from Native subordinates-lessons that Woolsey and Swilling had failed to learn but that the Rocas had mastered. In 1895, Hall wrote that in "reference to [the] feasibility of placing Indian pupils in white families, I have the honor to state that we have quite a number of pupils 'working out,' there being a larger demand for the pupils than we possibly can fill at this time." ${ }^{6}$ Within a year, Hall was bragging, "[had] I 500 Indian girls and boys of sufficient size and training, capable of understanding English to the extent of doing what they are told, I am sure places could be secured in this thickly settled valley inside ten days." 57 Clearly, Native indenture had fallen out of favor, but the demand for minor Indian labor increased in step with the Anglo population.

Territorial Arizona's indenture period reflects the pivotal transition between the extralegal traffic in minor Indian labor prior to 1864 and the institutional traffic in minor Indian labor after 1894. Though reformers intended to guard indigenous children from abuse and exploitation, the outing system continued to vest in citizen Arizonans an unquestioned authority over Native American women's and children's bodies and ensured that non-Indian households benefited from their labors. Once integrated into the progressive model of federal Indian policy, the indigenous labor market shifted from an extralegal slave trade to a curriculum of dependent relations within one generation. That dramatic change likewise transformed Clara Martínez, indentured daughter of an Apache slave, to Clara Woolsey, favored daughter of a pioneer Indian fighter. Gavílan Pollero, minor child of a "hostile Indian tribe," became Guillermo Swilling, Native sidekick to a territorial desperado. And Apache toddler Teutílla became Mexican criada Tontíllar Roca. 
These transformations reflect the creative chronicling of Arizona's intercultural households as "gentling" institutions rather than legislated sites that linked exploitative labor with intercultural intimacy. Ironically, the Howell Code ensured that Indian women and children nurtured and cared for citizens, while white heads of households craved the company of their Indian subordinates despite territorial senators' efforts to deter bonds of affection through the indenture mandate. Clara's decision sometime after 1880 to take her father's surname, Guillermo's staged jest as Swilling's bodyguard, and Tontíllar's pledge to serve the Rocas faithfully all posed problems for nineteenth-century legislators and continue to do so for twenty-first-century historians. Senators barred Clara Martínez from inheriting her father's wealth but not from inheriting his pioneer legacy. The Howell Code's statute on minor Indians disarmed Gavílan Pollero's Apache family members, but Jack Swilling put a gun in Guillermo's hands. The Pima County probate judge would not have accepted Teutílla's testimony against the Rocas, but he accepted the three-year-old's oath of indenture to them. Explicitly drafted in the interests of white patriarchy, the territorial legal code could not stand up to the everyday intricacies within territorial borderlands communities. Bonds of affection, though not always mutual, blurred the indenture contracts that made Arizona's Indian children vulnerable-and forgettable-members of white pioneer households.

\section{NOTES}

1. In 1864 the native-born white population in Arizona was not over 6oo, and ethnic Mexicans made Arizona's white population more like 6,500, a slim majority over the territory's 4,000 "civilized" Indians. These demographics threatened Arizona's prospects for statehood. See Thomas Edwin Farish, History of Arizona: Volume II (Phoenix, AZ: Filmer Brothers Electrotype Co., 1915), 322-23; and Katherine Benton-Cohen, Borderline Americans: Racial Division and Labor War in the Arizona Borderlands (Cambridge, MA: Harvard University Press, 2009), 7-16.

2. James F. Brooks, Captives and Cousins: Slavery, Kinship, and Community in the Southwest Borderlands (Chapel Hill: University of North Carolina Press, 2002); and Karl Jacoby, Shadows at Dawn: A Borderlands Massacre and the Violence of History (New York: Penguin Books, 2008).

3. Brooks, Captives and Cousins; Juliana Barr, "From Captives to Slaves: Commodifying Indian Women in the Borderlands," Journal of American History 92, no. 1 (June 2005): 19-46; Albert Hurtado, "'Hardly a Farm House-A Kitchen without Them': Indian and White Households on the California Borderland Frontier in 1860," Western Historical Quarterly 13, no. 3 (July 1982): 245-70; Margot Mifflin, The Blue Tattoo: The Life of Olive Oatman (Lincoln: University of Nebraska Press, 2009); and Victoria Smith, Captive Arizona, 1851-190o (Lincoln: University of Nebraska Press, 2009).

4. John Goff, King S. Woolsey (Cave Creek, AZ: Black Mountain Press, 1981), 48.

5. William T. Howell, Howell Code Adopted by the First Legislative Assembly of the Territory of Arizona, 1864 (Prescott: Office of the Arizona Miner, 1865); and Martha Hodes, ed., Sex, Love, Race: Crossing Boundaries in North American History (New York: New York University Press, 1999).

6. John S. Goff, "William T. Howell and the Howell Code of Arizona," American Journal of Legal History 11, no. 3 (July 1967): 221-33. 
7. An excellent discussion of age of consent laws and their reform can be found in Leslie K. Dunlap, "The Reform of Rape Law and the Problem of White Men: Age of Consent Campaigns in the South, 1885-1910," in Sex, Love, Race: Crossing Boundaries in North American History, ed. Martha Hodes (New York: New York University Press, 1999), 352-72. Although Arizona's age of consent law did not differ radically from those already in place in other parts of the country, the statute remains worthy of scrutiny. When combined with the witness exclusion law and the minor Indian indenture provision, the age of consent law made Indian minors particularly vulnerable to the sexual desires of citizens around them because this legal triad abolished their ability to give or withhold consent.

8. Albert Hurtado, Intimate Frontiers: Sex, Gender, and Culture in Old California (Albuquerque: University of New Mexico Press, 1999), 21-44; Howell, Howell Code, 75, 76, 237, 444; and John P. Hoyt, The Compiled Laws of the Territory of Arizona, Compiled and Arranged by Authority of an Act of the Legislative Assembly, Approved February 9, 1877 (Detroit: Richmond, Backus \& Co., 1877), 50. See also Fernandez v. State of Arizona (1914), Case No. 360, Arizona Court of Appeals, Division One, Criminal Files, Briefs and Records, Arizona State Library, Archives and Public Records (hereafter ASLAPR). This case is discussed at length in the author's dissertation, Katrina Jagodinsky, "Intimate Obscurity: American Indian Women in Arizona Households and Histories, 1854-1935," Ph.D. diss, University of Arizona, 2011.

9. Howell, Howell Code, 230.

10. Martha Menchaca, "Chicano Indianism: A Historical Account of Racial Repression in the United States," American Ethnologist 20, no. 3 (Auguist 1993): 583-603; and Peggy Pascoe, "Race, Gender, and Intercultural Relations: The Case of Interracial Marriage," Frontiers: A Journal of Women Studies 12, no. 1 (1991): 5-18. Both Menchaca and Pascoe illustrate that Mexican women faced discrimination under miscegenation laws even though they were legally white because jurists could use phenotypes to rule that they were in fact Indian and therefore banned from intermarrying with whites-which could include other Mexicans.

11. Kathleen Brown, Good Wives, Nasty Wenches, and Anxious Patriarchs: Gender, Race, and Power in Colonial Virginia (Chapel Hill: University of North Carolina Press, 1996); and Jennifer Morgan, Laboring Women: Reproduction and Gender in New World Slavery (Philadelphia: University of Pennsylvania Press, 2004).

12. Some legislators likely brought to Arizona miscegenation fears shaped under antebellum and reconstruction contexts similar to those discussed in Peggy Pascoe, What Comes Naturally: Miscegenation Law and the Making of Race in America (New York: Oxford University Press, 2009), and applied "commonsense" definitions of race such as those described in Ariela J. Gross, What Blood Won't Tell: A History of Race on Trial in America (Cambridge, MA: Harvard University Press, 2008).

13. George H. Kelly, Legislative History: Arizona, 1864-1912 (Phoenix, AZ: Manufacturing Stationers, 1926), 6 .

14. Sondra Jones, “'Redeeming the Indian': The Enslavement of Indian Children in New Mexico and Utah," Utah Historical Quarterly 67, no. 3 (1999): 220-24; and Michael Magliari, "Free Soil, Unfree Labor: Cave Johnson Couts and the Binding of Indian Workers in California, 1850-1867," Pacific Historical Review 73, no. 3 (August 2004): 349-89.

15. Howell, Howell Code, 428.

16. Stacey Leigh Smith, "California Bound: Unfree Labor, Race, and the Reconstruction of the Far West, 1848-1870," Ph.D. diss., University of Wisconsin-Madison, 2008, 411; Hoyt, Compiled Laws of Arizona, 315; and James A. Bayard, Revised Statutes of Arizona (Prescott, AZ: Prescott Courier Print, 1887), 567.

17. Smith, Captive Arizona.

18. In Laboring Women, Morgan argues that sexual and economic access to laboring women's bodies constitutes a fundamental component of American masculinity. 
19. Evelyn Nakano Glenn, "From Servitude to Service Work: Historical Continuities in the Racial Division of Paid Reproductive Labor," Signs 18, no. 1 (Autumn 1992): 1.

20. That male servants bore no children as a result of sexual assault and were also barred from testifying against their masters makes it virtually impossible to determine the frequency of sexual exploitation of Indian boys indentured under the Howell Code, although in theory the sodomy law, outlined in the same article as the rape statute, would have applied to them.

21. Goff, King S. Woolsey, 54-73.

22. John Nicolson, ed., The Arizona of Joseph Pratt Allyn, Letters From a Pioneer Judge: Observations and Travels, 1863-1866 (Tucson: University of Arizona Press, 1974), 81.

23. Kirsten Fischer, Suspect Relations: Sex, Race, and Resistance in Colonial North Carolina (Ithaca, NY: Cornell University Press, 2002), 98-158.

24. See Joaquín Rivaya-Martínez's chapter in this volume and Smith, Captive Arizona.

25. Census data gathered for this chapter has been accessed through Ancestry.com and can be reviewed through both the name search and browsing features. Citation information provided by Ancestry.com is given here for those without access to the online database, which requires a subscription. Tenth Census of the United States, 1880 (Washington, DC: National Archives and Records Administration, 1880), Roll T9-37; Goff, King S. Woolsey, 18-20, 74-82; "Henry S. Fitzgerald, Guardian of Clara and Johanna Woolsey, Minors, vs. M.W. Kales, Administrator of the Estate of King S. Woolsey, Deceased" (May 1880), Case No. 146 in MSS 110, Benjamin Sacks Collection of the American West (hereafter Sacks), Series 1, Box 30, Folder 8, Arizona Historical Foundation (hereafter AHF); and "Lucia Martinez vs. Thomas Barman, K.S. Woolsey, John Ammerman, and Mrs. Ammerman" and "Lucia Martinez and King Woolsey," Maricopa County Probate Court Record Book (1871-74), 6-8 and 15, Record Group (hereafter RG) 107, Maricopa County, Subgroup (hereafter SG) 8, Superior Court, ASLAPR.

26. Civil Case No. 146, RG 107, SG 8, ASLAPR; "In the Matter of the Estate of King S. Woolsey (1879)," Maricopa County Superior Court Civil Case No. 32, RG 107, SG 8, ASLAPR; and Goff, King S. Woolsey, 65-73, 78-79.

27. Civil Case No. 32, RG 107, SG 8, ASLAPR.

28. Arizona Sentinel, November 19, 1880, in Sacks, MSS 110, Series 1, Box 30, Folder 8, AHF; "Clara Woolsey vs. M. W. Kales, Administrator" (1880), in Sacks; Phoenix Herald, October 24, 1881, in Sacks, MSS 110, Series 1, Box 30, Folder 8, AHF; and Tenth Census, Roll T9-37. Though the 1930 census schedules are the only forms that offer an option to report Mexican ethnicity, territorial Arizona enumerators often wrote " $M$ " or "Mex" to indicate Mexican ethnicity, and Arizonans listed as "W" for white can be identified as ethnic Mexicans through Sonoran birthplaces listed in the census.

29. "Editorial," Arizona Sentinel, October 5, 1878, in Sacks, MSS 110, Series 1, Box 30, Folder 8, AHF.

30. Arizona Republic, July 27,1947 , in Sacks, MSS 110, Series 1, Box 30, Folder 8, AHF.

31. Goff, King S. Woolsey, 80-81; and James M. Barney, "Col. King S. Woolsey, Famous Arizona Pioneer: The Story So Far, Vol. 8," The Sheriff (1948), in the James M. Barney Collection, MSS 4, Box 1, Folder 7, AHF.

32. Albert R. Bates, Jack Swilling, Arizona's Most Lied About Pioneer (Tucson, AZ: Wheatmark, 2008); Michael R. Wilson, Tragic Jack: The True Story of Arizona Pioneer John William Swilling (Guilford, CT: Two Dot, 2007); and Earl Zarbin, The Swilling Legacy (Phoenix, AZ: Salt River Project, 1984).

33. "Statement of Mrs. Trinidad Shoemaker (formerly Mrs. Jack Swilling)," p. 5, CM MSM 667, Arizona Collection, Hayden Library, Arizona State University Department of Archives and Special Collections. 
34. Wilson, Tragic Jack, 11; and Bates, Jack Swilling, 55, 59.

35. United States Department of Census, Federal Census-Territory of New Mexico and Territory of Arizona: Excerpts from the Decennial Federal Census, 1860, for Arizona County in the Territory of New Mexico, the Special Territorial Census of 1864 Taken in Arizona and Decennial Federal Census, 1870, for the Territory of Arizona (Washington, DC: United States Government Printing Office, 1965); and Ninth Census of the United States, 1870 (Washington, DC: National Archives and Records Administration), RG 29; Roll M593-46, p. 103, image 194.

36. Zarbin, Swilling Legacy, 6-7; and Bates, Jack Swilling, 54-55.

37. Jacoby, Shadows at Dawn, 247. Jacoby also demonstrates that Americans shared similar fears (223).

38. Zarbin, Swilling Legacy, 3; Wilson, Tragic Jack, 42; and "A. J. Ammerman vs. J. W. Swilling," Maricopa County Probate Court Record Book (1871-74), 4-8, RG 107, Maricopa County, SG 8, Superior Court, ASLAPR. These probate records indicate that there was some relationship between John Ammerman and King Woolsey as well, since Ammerman sued Swilling for Bonifácio and Guadalupa Woolsey, and Lucía Martínez named Ammerman in her suit against Woolsey for custody of Clara and Johanna Woolsey. Ammerman may have been seeking custody of Indian children associated with Woolsey as a favor to the Colonel, who was unwilling to keep them after his marriage to Mary Taylor. Swilling's indenture of Guillermo Swilling immediately followed Woolsey's indenture of Clara and Johanna Martínez. See "Indenture of Guillermo Swilling," Maricopa County Probate Court Record Book (1871-74), 16-17, ASLAPR.

39. "Photograph of Jack Swilling, an Early Settler of Phoenix (Ariz.), and a Native American Man," ca. 1875, RG 99, SG 12, Historical Photographs, ASLAPR; and Bates, Jack Swilling, 59.

40. Bates, Jack Swilling, 59; and Wilson, Tragic Jack, 11.

41. Farish, History of Arizona, Volume II, 256.

42. Wilson, Tragic Jack, 63-85.

43. José Luís Blasio, Maximilian, Emperor of Mexico: Memoirs of His Private Secretary, trans. Robert Hammond Murray (New Haven, CT: Yale University Press, 1934); Egon Corti, Maximilian and Charlotte of Mexico, 2 vols., trans. Catherine Alison Philips (New York: Alfred A. Knopf, 1928); and Bertida Harding, The Phantom Crown: The Story of Maximilian and Carlota of Mexico (New York: Halcyon House, 1934).

44. Letter by Paul M. Roca in Miguel Gonzales Roca Hayden Bio File, Arizona Historical Society (hereafter AHS).

45. George H. Smalley with Yndia Smalley Moore, ed., My Adventures in Arizona: Leaves from a Reporter's Notebook (Tucson: Arizona Pioneers' Historical Society, 1966), xi, xii, 39; Bernice Cosulich, Tucson: The Fabulous Story of Arizona's Ancient Walled Presidio, 1692-190o's (Tucson: Arizona Silhouettes, 1953), 206; James E. Officer et al., Arizona's Hispanic Perspective: Research Report Prepared by the University of Arizona, May 17-20, 1981 (Phoenix: Arizona Academy, 1981), 68, 78; Laura E. Gómez, Manifest Destinies: The Making of the Mexican American Race (New York: New York University Press, 2007), 109; and Tenth Census, Roll T9-36, p. 327, image 0669.

46. Mark A. Burkholder and Lyman L. Johnson, Colonial Latin America, 3rd ed. (New York: Oxford University Press, 1998), 116-32, 194-219; and Maria Eugenia Chaves, "Slave Women's Strategies for Freedom and the Late Spanish Colonial State," in Hidden Histories of Gender and the State in Latin America, ed. Elizabeth Dore and Maxine Molyneux (Durham, NC: Duke University Press, 2000), 108-26.

47. Nara Milanich, "The Casa de Huerfanos and Child Circulation in Late-Nineteenth-Century Chile," Journal of Social History 38, no. 2 (Winter 2004): 311-40.

48. Smalley, My Adventures in Arizona, xii; "Case No. 41.5 (1869)," Box 88, RG 110, Pima County Probate Records, 1864-1924, ASLAPR; Ninth Census, RG 29, M593-46, p. 56, image 106. 
49. “Case No. 41.5 (1869)."

50. Ninth Census, RG 29, Roll M593-46, p. 56, image 106; and Tenth Census, Roll T9-36, p. 327, image 0669 .

51. Officer et al., Arizona's Hispanic Perspective, 73-82; Smalley, My Adventures, 38; Thomas E. Sheridan, Los Tucsonenses: The Mexican Community in Tucson (Tucson: University of Arizona Press, 1986), 215, 120; and MS 1374, Heney Family, Box 1, Folder 13, and Paul McLennan Roca Hayden Biofile, AHS.

52. According to archivists at the Arizona Historical Society, the flag stand has been lost.

53. See Miguel Roca Hayden Biofile and MS 1374, Heney Family, Box 1, Folder 1, AHS.

54. Case No. 37, Record Group 114, Yuma County Superior Court Probate Division and Maricopa County Probate Court Record Book (1871-74), 575, RG 107, Maricopa County, SG 8, Superior Court, ASLAPR.

55. David Wallace Adams, Education for Extinction: American Indians and the Boarding School Experience, 1875-1928 (Lawrence: University of Kansas, 1995), 162-63; Margaret D. Jacobs, "Working on the Domestic Frontier: American Indian Domestic Servants in White Women's Households in the San Francisco Bay Area, 1920-1940," Frontiers: A Journal of Women Studies 28, no. 1/2 (2007): 165-99; Robert Trennert Jr., Phoenix Indian School: Forced Assimilation in Arizona, 1891-1935 (Norman: University of Oklahoma Press, 1988); Robert Trennert Jr., "From Carlisle to Phoenix: The Rise and Fall of the Indian Outing System, 1878-1930," Pacific Historical Review 52, no. 3 (August 1983): 267-91; and Robert Trennert Jr., "Victorian Morality and the Supervision of Indian Women Working in Phoenix," Journal of Social History 22, no. 1 (Autumn 1988): 113-28.

56. Harwood Hall to Commissioner of Indian Affairs, January 16, 1895, in Robert Trennert Papers, Box 2, Folder 2, Labriola National American Indian Data Center, Arizona State University Library, Archives and Special Collections Division (hereafter Labriola Center).

57. Harwood Hall to Commissioner of Indian Affairs, January 11, 1896, in Robert Trennert Papers, Box 2, Folder 3, Labriola Center. 